
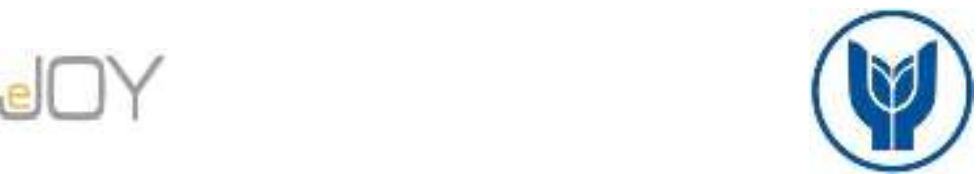

Güler, O., Yayla, F., Öztürk, M. / Journal of Yasar University, 2021, 16/61, 170-192

\title{
Çocuklu Ailelerin Restoran Seçim Kriterleri ve Hizmet Kalitesi Algıları: Önem-Performans Analizi ile Bir Araştırma ${ }^{1}$ \\ Restaurant Selection Criteria and Service Quality Perception of Families with Children: A Research through Importance-Performance Analysis
}

\author{
Ozan GÜLER, Mersin Üniversitesi, Türkiye, ozanguler@mersin.edu.tr \\ Orcid No: 0000-0002-0062-3983 \\ Fatma YAYLA, Mersin Üniversitesi, Türkiye, ftmyyla@gmail.com \\ Orcid No: 0000-0002-7470-9798
}

Metin ÖZTÜRK, Adıyaman Üniversitesi, Türkiye, ozturkmetin14@gmail.com

Orcid No: 0000-0001-9462-8226

\begin{abstract}
Öz: Bu araștırmanın amacl; çocuklu ailelerin alakart restoran seçimlerinde önem verdikleri kriterleri ve bu kriterlerden hareketle algıladıkları hizmet kalitesini önem-performans bakış açısıyla araştırmaktır. İlişkisel tarama modeliyle tasarlanan araştırmada çevrimiçi anket yoluyla 359 ebeveynden veri toplanmuştır. Istatistiksel analiz olarak betimleyici istatistikler, fark testleri ve önem-performans analizi (ÖPA) gerçekleştirilmiştir. Elde edilen bulgular, çocuklu ailelerin restoran seçim kriterlerinin tümünü önemli bulmakla beraber en az öneme sahip boyutun çocuk dostu hizmetler olduğunu göstermektedir. ÖPA bulgularına göre, müşterilerin yüksek önem verdiği ancak performans olarak zaylf bulduğu çocuk dostu hizmetler; emzirme ve alt değiştirme odası ve mama sandalyesi/çocuk masası hizmetlerinin niteliğidir. Ek olarak restoranların çocuklu aileleri mutlu etmek için yoğunlaşması gereken diğer hizmetler; alınan hizmetin ödenen paraya değmesi, restoranın temiz ve hijyenik olması, profesyonel hizmet sunumu ve çalışanların genel iletişim becerileri şeklindedir.
\end{abstract}

Anahtar Kelimeler: Aile Tüketim Davranışı, Çocukların Tüketimdeki Rolü, Restoran Seçimi, Hizmet Kalitesi, Önem-Performans Analizi

JEL Sinfflandirmasi: L83, M21, M31

Abstract: The aim of this study is to investigate the criteria that families with children attach importance to in their à la carte restaurant selection and to perceived service quality based on importance-performance criteria. In the study designed with the relational screening model, data were collected from 359 parents through online questionnaires. As statistical analysis, descriptive statistics, difference tests and importance-performance analysis (IPA) were performed. Findings show that while families with children find all the restaurant selection criteria important, the least important dimension is child-friendly services. IPA findings reveal that childfriendly services, which customers attach high importance to but find poor performance, are "breastfeeding and diaper changing room and high chair/child table". In addition, other services that restaurants should focus on in order to provide better quality service are; worth the money paid, clean and hygienic restaurant, professional service delivery and the general communication skills of the employees.

Key Words: Family Buying Behavior, Role of Children in Consumption, Restaurant Selection, Service Quality, Importance-Performance Analysis

JEL Classification: L83, M21, M31

\section{Giriş}

Müşteri, tüm mal ve hizmet üreten işletmelerin pazarlama karması elemanlarının ana noktasında yer alır. Müşterilerin bir mal ya da hizmetten ne bekledikleri ya da neye önem verdikleri gibi sorulara yanıt aramadan anlamadan işletmelerin başarıya ulaşmaları olası

\footnotetext{
${ }^{1}$ Bu Çalışma İçin Mersin Üniversitesi Sosyal Bilimler Etik Kurulu'ndan 08/10/2020 tarihli ve 37 karar numaralı “Etik Kurul Onayı" alınmıştır.
} 
değildir (Albayrak, 2014a: 190). Bununla birlikte günümüz müşterilerinin beklentileri ve davranışları, dünyadaki her şey gibi büyük bir hızla değişmektedir. Hizmet ağırlıklı işletmeler bu değişimi çok daha belirgin hissederler ve bu işletmelerin başında yiyecek-içecek işletmeleri gelmektedir. Bir yiyecek-içecek işletmesinin hizmet standardı ne kadar yüksek olursa olsun, müşterilerin beklentileri ile sunulan hizmet performansı arasında farklılıklardan kaynaklı hizmet başarısızlıklarının ortaya çıkması sık rastlanılan bir durumdur (Hart, Heskett \& Sasser, 1990: 148; Yang \& Mattila, 2012: 399). Yiyecek-içecek işletmelerinin içinde bulunduğu rekabet koşulları (Albayrak, 2014a: 190), müşterilerle olan ilişki seviyesinin yüksekliği ve çoklu iletişim kurma süreci (Koç, 2008: 38) hizmetin kendisine has özellikleriyle birleşince (Kotler, Bowen \& Makens, 2010: 35) müşterilerin hizmet kalitesi ve memnuniyetlerine yönelik şikâyetler çok sık karşılaşılan bir durum haline gelmektedir.

Restoran işletmeleri örnekleminde gerçekleştirilen araştırmalar, hizmet kalitesinin müşteri memnuniyeti ve olumlu davranışsal eğilimler sağlamada anahtar bir değişken olduğunu ortaya koymuştur (Cronin, Brady \& Hult, 2000; Yüksel \& Yüksel, 2003; Pedraja-Iglesias \& Jesus Yagüe Guillen, 2004; Tam, 2004; Babin, Lee, Kim \& Griffin, 2005; Lee, Park, Park, Lee \& Kwon, 2005; Ha \& Jang, 2010; Ryu \& Han, 2010). Hizmet kalitesinin ölçümünde çoğunlukla Parasuraman, Zeithaml \& Berry'nin (1988) geliştirdiği SERVQUAL, Cronin \& Taylor'ın geliştirdiği SERVPERF (1992) ve Stevens, Knutson \& Patton’un (1995) geliştirdiği DINESERV ölçeği kullanılarak çeşitli istatistiksel analizler gerçekleştirilmiştir. Bu analizlerden birisi de Martilla \& James'in (1977) ortaya koyduğu Önem-Performans Analizi'dir (ÖPA). ÖPA, tüketici beklentilerinin ve sunulan hizmete yönelik performans algılarının sonucu olarak memnuniyeti ortaya koyan bir analiz türüdür. ÖPA bulguları, işletmelerinin uygulamaya yönelik kolay ve hızlı çıkarımlar yapmasını sağlayarak pazarlama karmalarını ekonomik olarak kullanmalarına ve pazarlama karar süreçlerinin verimliliğine yardımcı olabilir (Martilla \& James, 1977: 79; Hansen \& Bush, 1999: 126).

ÖPA, turizm ve ağırlama alanyazınında sıklıkla başvurulan bir teknik olmakla beraber, farklı nitelikteki yiyecek içecek işletmeleri örnekleminde de sıklıkla kullanılan bir tekniktir (Choi \& Jung, 2006; Yoon, 2008; Ma, Qu, \& Njite, 2011; Tzeng \& Chang, 2011; Obonyo, Ayieko \& Kambona, 2012; Su, 2013; Albayrak, 2014b; Chen, 2014; Sohn \& Kim, 2014; Kaya, 2017; K1lıç, Esen \& Esen, 2017; Liu \& Tse, 2018; Pai, Yeh \& Tang, 2018; Wu, Weng, Lin, Kim \& Gotcher, 2020). Buna karşın bu çalışmalarda tüketicilerin kalite algıları bireysel olarak değerlendirilmeye alınırken, restoran işletmeleri için çok önemli bir örneklem olan çocuklu aileler göz ardı edilmiştir. Farklı beklentilere sahip nispeten kalabalık bireylerden oluşan bu aileleri restoranlar için daha da kritik yapan koşulların başında ise kuşkusuz 
çocukların varlığı gelir. Alanyazında yapılan araştırmalar çok uzun zamandır ailelerin dışarıda yemek yeme kararları üzerinde çocukların önemli bir role sahip olduğunu göstermektedir (Szybillo \& Sosanie, 1977; Nelson, 1979; Assael, 1987; Swinyard \& Sim, 1987; Labrecque \& Ricard, 2001; Nayak, 2015).

Çocuklu ailelerin tüketim davranışları restoran seçim kriterleri bağlamında ele alınan bir konudur. Buna karşın çoğunlukla birkaç ifade ile genel restoran seçim kriterleri arasında yer alarak araştırılan çocuk dostu hizmetler (Miller \& Ginter, 1979; Auty, 1992; Kara, Kaynak \& Küçükkemiroğlu, 1996; Arıker, 2012), sınırlı sayıda araştırmada kapsamlı olarak ele alınmıştır (Elder ve ark. 1999; Pettersson \& Fjellström, 2007; Ertürk, 2009a; Ertürk, 2009b; Akşit Aşık, 2019). Çocukların varlığı çocuksuz ailelere göre daha da farklı tüketici istek ve beklentilerine yol açmaktadır (Aymankuy \& Ceylan, 2013: 106). Bu nedenle, çocuklu ailelerin restoran tercihinde etkili olan faktörlerin öğrenilmesi restoranlara, çocukları üzerinden müşterileri memnun etmenin yolunu öğreterek (Nayak, 2015: 95) yoğun rekabet ortamında rakiplerine karşı yenilikçi fikirler ile avantajlı hale gelme fırsatı sağlamaktadır (Nayak, 2015: 95; Akşit Aşık, 2019: 151). Sonuç olarak hem alanyazına hem de uygulamaya yönelik önem ve ihtiyaçtan hareketle gerçekleştirilen bu araştırmanın amacı; çocuklu ailelerin alakart restoran seçimlerinde önem verdikleri unsurları ve bu unsurlardan algıladıkları hizmet kalitesini önem-performans ilişkisinden hareketle ortaya koymaktır.

\section{Kavramsal Çerçeve ve Alanyazın Taraması}

\subsection{Aile Tüketim Davranışı ve Çocukların Rolü}

Tüketici davranışları alanyazınında son 50 yıldır üzerinde durulan ve önemli bir konu olan aile tüketim davranışı (Filiatrault \& Ritchie, 1980: 131; Nayak, 2015: 95), başlangıçta çoğunlukla eşlerin rolleri bağlamında ele alınmıştır (Swinyard \& Sim, 1987: 26; Howard \& Madrigal, 1990: 245; Şen Demir \& Kozak, 2013: 71). Önceleri aile içinde en fazla gelire sahip olan bireyin erkek olduğu ve karar verme mekanizmasında (eğitim, iş, ev alma vb.) en tepede olduğu düşünülerek, kadın ve çocuğun rolü göz ardı edilmekteydi (Cunningham \& Green, 1974: 61; Swinyard \& Sim, 1987: 26; Howard \& Madrigal, 1990: 245; Koç, 2008: 273; Şen Demir \& Kozak, 2013: 71). Ancak zaman içerisinde dünyada meydana gelen sosyo ekonomik gelişmeler neticesinde tüketim kararı rolleri daha eşit hale gelmiştir (Swinyard \& Sim, 1987: 26; Howard \& Madrigal, 1990: 245; Şen Demir \& Kozak, 2013: 71; Nayak, 2015: 95). Çocuklar aile içindeki gıda satın alma sürecinde aktif rol alarak ebeveynlerinin satın alma eylemlerinde aracı rol oynarlar (Nørgaard, Bruns, Christensen \& Mikkelsen, 2007: 208). İlk bakışta çocuğun doğrudan tüketime katıldığı ürünlerin aile tüketim kararları üzerinde en güçlü etkiye sahip olması beklenirken (Martensen \& Gronholdt, 2008: 15), zaman içerisinde bu 
etkinin çocuk merkezli ürünlerden (oyuncaklar, çocuk giysileri vb.) tüm aile bireylerini ilgilendiren mal ve hizmetlere kadar (tatil planları, eğlence, restoran seçimi) birçok tüketim kararında etkili olmaya başladığı görülmüştür (Swinyard \& Sim, 1987: 26; Howard \& Madrigal, 1990: 245; Aygün \& Kazan, 2008: 233)

Çocukların aile tüketim davranışlarındaki rollerini araştıran çalışmalar çeşitli teorik arka planlardan faydalanmışlardır. Bu teorilerin başında Kaynak Teorisi ve Tüketici Sosyalleşme Teorisi gelmektedir. Kaynak teorisi, çocukların karşılaştırmalı kaynakları (gelir katkısı, istihdam durumu, eğitim, okul notları, ebeveyn sevgisi ve duygusu ve doğum sırası) ne kadar büyükse ailelerinin satın alma kararlarında o derece etkili olduklarını ileri sürer (Flurry, 2007: 324). Bir diğer teori olan tüketici sosyalleşme teorisi ise aile üyelerinin karar verme sürecindeki etkilerinin sosyalleştirilmiş normların ve rollerin bir fonksiyonu olduğunu ileri sürer (Mangleburg, Grewal \& Bristol, 1999: 380; Flurry, 2007: 324). Aile içi karar alma sürecinde çocukların etkisi; anne ve babaların otoriterlik seviyelerine göre (Carlson \& Grossbart, 1988); ebeveyn sayısı, çalışma rolleri ve sosyo-ekonomik özellikler (Howard \& Madrigal, 1990) ve farklı yaşlardaki tüketim davranışları (John, 1999) gibi kontrol değişkenleri bağlamında da incelenmiştir.

\section{2. Çocuklu Ailelerin Restoran Tercihi Üzerine Alanyazın Taraması}

Çocukların en etkili olduğu tüketim kararlarından birisi de dışarıda yemek yeme faaliyetidir (Swinyard \& Sim, 1987; Labrecque \& Ricard, 2001: 175; Nayak, 2015; Chen, Lehto, Behnke \& Tang, 2016: 14-15). Dışarıda yemek yemeye ilişkin tüketici kararları; yenecek yemeğe karar verme ve yemek yenecek restorana karar verme şeklinde ikiye ayrılabilir (Özdemir, 2010: 226-227). Çocuğun aile yeme kararlarına katılımı ise altı karar aşamasında ele alınır. Aşamalar arasında problem tanıma, bilgi sağlama, restoran türüne karar verme, belirli bir restorana karar verme, ne kadar harcanacağına karar verme ve son kararı verme şeklindedir (Nelson, 1979: 419). Beş yaşın üzerindeki çocukların, problem tanıma, bilgi sağlama, restoran türüne karar verme ve belirli bir restorana karar verme konusunda ebeveynler kadar katılımlı olduklarını göstermektedir (Nelson, 1979: 419). Elder ve ark. (1999) Amerika Birleşik Devletleri'nde (ABD) yaşayan İngiliz ve Meksika kökenli Amerikalı ailelerin restoran seçim kriterlerini öğrenmek ve karşılaştırma yapmak amacıyla bir araştırma gerçekleştirmişlerdir. Araştırma bulguları aile bireylerinin restoran seçim kriterlerinin restoran türlerine göre belirgin şekilde değiştiğini göstermektedir. Masaya servis yapan restoranlar söz konusu olduğunda, salata barı ve düşük kalorili yemeklerin tercih açısından ön planda olduğu görülmektedir. Pettersson \& Fjellström (2007) İsveç’in Stockholm ve Upsalla şehirlerinde yer alan fast food restoran ve masa servisi yapan restoranlar örnekleminde gözlem tekniğini 
kullanarak gerçekleştirdikleri araştırmalarında; emzirme odası bulunması, çocukların pusetlerinin rahat edebileceği alanların olması, mobilyaların temizlenmesi, kâğıt peçete bulunması gibi unsurların önemli olduğunu bulgulamışlardır.

Akşit Aşık (2019) farklı özellikteki restoran müşterileri örnekleminde yaptığı araştırmasında çocuklu ailelerin restoran tercihlerinde en fazla önem verdikleri boyutun yemeklerin niteliği olduğunu buna karşın çocuk dostu hizmetlerin en az önem verilen boyut olduğunu bulgulamıştır. Çocuk dostu hizmetler boyutu içerisinde en yüksek tercih sebebi oluşturan unsurlar sırasıyla; çocuklar için oyun odasının bulunması, çocuklara hediyeler verilmesi ve yeşil alan/bahçe bulunması şeklindedir. Ek olarak çocuk dostu hizmetleri önemli gören ailelerin öncelikli tercihlerinin lüks restoranlar olduğu da bulgulanmıştır. Ertürk (2019a) 12 ve altındaki yaşlarda çocuk sahibi olan ailelerin dışarıda yeme içme alışkanlıklarını araştırmıştır. Katılımcılar çocuklarının mutlu olacağı, sağlıklı yiyecekler yiyebileceği ve yetişkin aile bireylerinin kendilerini rahat hissedebileceği restoranlar için yaklaşık \%50 oranında daha fazla ödemeye katlanabileceklerini ifade etmişlerdir. Ertürk (2019b) bir diğer araştırmasında 12 ve altındaki yaşlarda çocuk sahibi olan 18 ebeveyn ile yüz yüze görüşmeler gerçekleştirmiştir. Bu araştırmada daha çok restoranlarda karşılaşılan hizmet aksaklıkları üzerinde durularak tüketicilerin hizmet beklentileri araştırılmıştır. Mülakatlar neticesinde ebeveynler için en önemli konuların; yiyecek ve içeceklerin sağlıklı olması, restoran atmosferi, çocuk oyun alanlarının hijyeni ve çocukların kullanımına uygun mutfak ekipmanları olduğu anlaşılmaktadır.

\subsection{Restoran Hizmet Kalitesi}

Hizmet kalitesi, gerek kavramsallaştırılması gerekse de ölçülmesi açısından pazarlama alanyazınında üzerinde mutabakatın olmadığı konuların başında gelir (Gronroos, 1988: 11; Hansen \& Bush, 1999: 119). Parasuraman, Zeithaml \& Berry (1985: 42) kaliteyi, "müşterilerin tüketimlerine yönelik performans beklentileri ile algıladıkları hizmet performansı karşıllaştırması neticesinde işletmeye ilişkin genel değerlendirmesi” olarak tanımlamışlardır. Kalitenin kavramsallaştırılmasına yönelik çalışmalar araştırmacıların kendi modellerini ve ölçümlerinin daha geçerli ve genellenebilir olduğu iddiasını kanıtlamaya yönelik çalışmalar ile devam etmiştir. Bu çalışmaların ilki ve hala en çok başvurulanı Parasuraman ve ark.'nın (1988: 36) özellikler/somutluk, güvenilirlik, heveslilik, güven ve empati alt boyutlarından oluşan SERVQUAL ölçeğidir. Gerçekleşen performans ile beklenen peformans ve arasındaki karşılaştırma sonucunda ortaya çıkan olumsuz fark, tüketicinin hizmet kalitesi algısının olumsuz; olumlu fark ise tüketicinin hizmet kalitesi algısının olumlu olduğunun bir göstergesidir (Kılıç, Ok \& Sop, 2013: 822). Olumsuz fark, memnuniyetsizliğe 
giden yolu aralarken, olumlu fark ise memnuniyeti ve olumlu davranışsal eğilimleri beslemektedir (Han, Kwortnik \& Wang, 2008: 26; Ha \& Jang, 2009: 319). Cronin \& Taylor (1992) kalitenin bir tutum olarak ölçülmesi gerektiğini ve sadece algılanan performans odaklı ölçümün (beklenti dâhil edilmeden) yeterli olacağını ileri sürerek, SERVPERF ölçeğini geliştirmiştir. Alanyazında restoranlarda algılanan hizmet kalitesi konusu Stevens, Knutson \& Patton'un (1995) geliştirdiği DINESERV ölçeği ile de yaygın şekilde ölçülmektedir. 22 maddeli SERVQUAL ölçeği temel alınarak geliştirilen DINESERV ölçeği de benzer şekilde 5 boyuttan oluşur ve toplam 29 maddeye sahiptir.

\section{4. Önem-Performans Analizi (ÖPA)}

ÖPA tekniği Martilla ve James (1977) tarafından geliştirilen, müşterilerin bir mal ya da hizmetten beklentilerine atfettikleri önem ile algıladıkları performansı iki boyutlu bir grafik üzerinde dört kümeli bir matris ile inceleyen bir analiz tekniğidir (Martilla ve James, 1977: 78; Hansen \& Bush, 1999: 126; Sever, 2015: 44). Bu dört küme işletmelerin sınırlı kaynakları göz önüne tutularak hizmet önceliklerinin neler olması gerektiği felsefesinden hareketle oluşturulmuştur (Sever, 2015: 44). Bu dört kategori Şekil 1'de görüleceği üzere; yoğunlaşılması gereken alanlar (keep up good work), korunması gerekenler (concantrate here), düşük öncelikler (low priority) ve olası aşırılıklar (possible overkill) şeklinde sinıflandırılır (Martilla ve James, 1977: 78; Hansen \& Bush, 1999: 126).

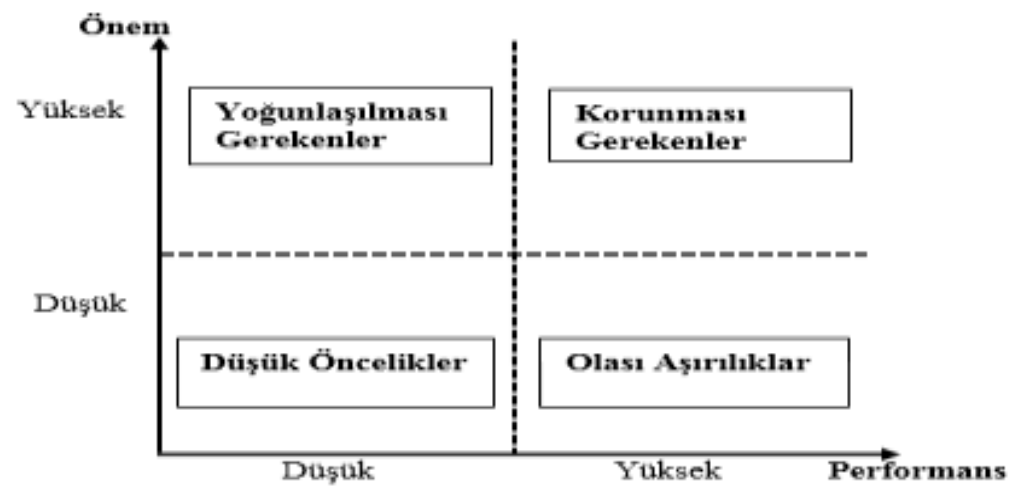

Şekil 1. ÖPA Matrisi

\subsection{Restoran Hizmet Kalitesini ÖPA Tekniği İle Araştıran Çalışma Özetleri}

ÖPA turizm pazarlaması başta olmak üzere çok çeşitli konuda başvurulan bir yöntemdir. Yerli ve yabancı alanyazın incelendiğinde turizm alanyazınında ÖPA tekniğinin kullanıldığı araştırmalar destinasyon kalitesi (Hudson \& Shephard, 1998; Albayrak \& Caber, 2011; Jeng, Snyder \& Chen, 2019), konaklama hizmetleri kalitesi (Chu \& Choi, 2000; Tekin, Kalkan \& Duman, 2014), tur hizmetleri kalitesi (Zhang \& Chow, 2004; Tetik, 2012) ve hava yolları 
hizmet kalitesi (Chiang Leong, 2008; Tsai, Hsu \& Chou, 2011; Erdoğan, 2020) bağlamında ele alındığ 1 görülmektedir. Bu alanlara ek olarak ÖPA tekniği farklı nitelikteki ve büyüklükteki yiyecek-içecek işletmelerinde hizmet kalitesi araştırmalarında da sıklıkla başvurulan bir tekniktir (Hsu, Byun \& Yang, 1998; Choi \& Jung, 2006; Yoon, 2008; Ma ve ark., 2011; Tzeng \& Chang, 2011; Obonyo ve ark., 2012; Su, 2013; Albayrak, 2014b; Chen, 2014; Sohn \& Kim, 2014; Kaya, 2017; Kılıç ve ark., 2017; Liu \& Tse, 2018; Pai ve ark., 2018; Wu ve ark., 2020). İlgili araştırmalar farklı niteliklerdeki restoranlarda gerçekleştirilmesine karşın çocuklu aile örnekleminde hizmet kalitesi ele alınmamıştır. Dolayısıyla bu araştırma çocuk dostu hizmetlerden algılanan kaliteyi de restoran tercih kriterlerine dâhil ederek daha kapsamlı bir şekilde konuyu irdelemektedir.

Hsu, Byun \& Yang (1998) üniversite öğrencileri gözünden farklı nitelikteki restoranlara yönelik hizmet kalitesi algısını ÖPA tekniğiyle analiz etmiştir. Aile restoranları noktasında ortaya çıkan bulgular, yemeklerin ve menülerin niteliğinin restoranların koruması gereken özellikler olduğu buna karşın temizlik, hizmet sunumu ve restoran atmosferi noktalarında restoranların yol kat etmesi gerektiğini göstermektedir. Amerika Birleşik Devletleri'ndeki Çin restoranları örnekleminde bir araştırma yapan Ma ve ark. (2011) restoranların yoğunlaşması gereken başlıca konuların; yemek kalitesi, fiyat ve personelin tutum-davranışları olduğunu ortaya koymuştur. Tayvan'daki en iyi 10 restoran örnekleminde SERVQUAL ölçeğini ve ÖPA modelini kullanarak bir araştırma yapan Tzeng \& Chang (2011) personelin hizmet sunumu odaklı sorunların alarm veren sorunlar olduğunu ortaya koymuştur. Buna göre, restoranın temizliği, müşteri istek ve ihtiyaçlarının beklenen profesyonellikte karşılanması, personelin müşteri sorularına cevap vermedeki bilgi düzeyi, müşterilere bireysel ilgi gösterilmesi ve müşterilerin özel istek ve beklentilerini anlayabilme yoğunlaşılması gereken konular arasındadır. Obonyo ve ark. (2012) tüketicilerin aksine yöneticilerin gözünden yemek hizmet kalitesine yönelik bir araştırma gerçekleştirmiştir. Araştırma bulguları üst düzey otel yöneticilerinin; hizmet ekipmanları, menü çeşitliliği, servis hızı, yemek servis tarzı ve fiyat konularının restoran yöneticilerinin çözmesi gereken sorunlar olduğunu düşündüklerini ortaya koymuştur. Su (2013) bireysel ve paket turla tatile çıkan turistler örnekleminde gerçekleştirdiği araştırmasında; gıda güvenliği, restoranın temizliği, personelin hizmet kalitesi ve yemek kalitesi konularının işletmelerin geliştirmesi gereken temel konular olduğunu ortaya koymuştur.

Albayrak (2014b) havalimanı restoranları örnekleminde gerçekleştirdiği araştırmasında; ödenen paranın karşılığını alma, çalışanların menüyle ilgili sorulara cevap vermeye istekliliğgi, siparişin istenildiği gibi gelmesi, hataların hemen düzeltilmesi ve yemeklerin çeşitliliği gibi 
noktaların restoranların yoğunlaşması gereken konular olduğunu ortaya koymuştur. Sohn \& Kim (2014) Japon restoranları örnekleminde yaptığı araştırmasında yemeklerin lezzeti ve servisin hızı konularının tüketicilerin önem verdiği ancak performans beklentilerinin altında kalan hizmetler olduğunu ortaya koymuştur. Liu \& Tse (2018) alakart restoran deneyimine sahip tüketiciler örnekleminde yapmış oldukları araştırmalarında; fiyat, ödenen paranın karşılığını alma, yemeklerin tazeliği, gıda güvenliği ve çalışanların menü bilgisi konularının restoran yöneticileri tarafından çözülmesi gereken konular olduğunu belirtmişlerdir. Pai ve ark. (2018), zincir restoranlar örnekleminde gerçekleştirdikleri araştırmasında DINESERV ölçeğinden hareketle önemi yüksek buna karşın performans algısı düşük olan tek konunun "hizmet başarısızlıklarının hızlı telafi edilmemesi” sorunu olduğunu belirtmişlerdir. Wu ve ark. (2020) Tayvan'ın en meşhur et restoranlarından birinde gerçekleştirdikleri araştırmalarında DINESERV ölçeğinden hareketle ortaya koydukları ÖPA bulguları; restoran atmosferinin çekiciliği, oturma takımlarının rahatlığı ve müşterilerin özel istek ve beklentilerini anlayabilme konularının restoranların odaklanması gereken sorunlar arasında olduğunu göstermektedir.

\section{Yöntem}

\subsection{Araştırma Modeli}

$\mathrm{Bu}$ çalışmanın amacı, çocuklu ailelerin masa servisi yapan restoranları seçerken önem verdikleri unsurları ve bu unsurlardan algıladıkları hizmet kalitesi algılarını önem-performans ilişkisinden hareketle ortaya koymaktır. Bu amaca ulaşabilmek için nicel araştırma yöntemi ile tasarlanan bu araştırmanın modeli ilişkisel tarama modeli olup, türü ise betimleyici araştırmadır. İlişkisel tarama modeli; iki veya daha çok değişkenin birlikte değişim derecesini araştıran, ilişkisel ve karşılaştırmaya yönelik araştırma yöntemidir. (Karasar, 2014: 77).

\subsection{Evren-Örneklem}

Araştırmanın evreni 12 ve altındaki yaşlarda çocuk sahibi olan tüm ebeveynlerdir. Çocukların tüketici davranışlarındaki rolü bebeklikten 12 yaşına kadar gelişmektedir (Valkenburg \& Cantor, 2001: 61-64). Ek olarak turizm endüstrisinde genellikle çocuklar 12 yaşına kadar çocuk olarak kabul edilir ve bu yaştan sonra yetişkin olarak değerlendirilirler (Ertürk, 2019a; 1596). Araştırmanın örneklemi ise mutfak kültürü açısından biribirine benzeyen ve araştırmacıların yaşadığı iki şehir olan Mersin ve Adıyaman şehirlerinde yaşayan, 12 yaş altı çocuğa sahip olan ve ayda en az 1 kere masa servisi yapan restoranları tercih eden bireylerden oluşmaktadır. Örnekleme ulaşma yöntemi olarak olasılıklı olmayan örnekleme yöntemlerinden kolayda örnekleme tekniğine başvurulmuştur. 


\subsection{Veri Toplama Aracı ve Süreci}

Veri toplama aracı olarak anket tekniğine başvurulmuştur. Anketin ilk bölümünde katılımcıların demografik ve dışarıda yemek yeme davranışlarını öğrenmeye yönelik 14 kategorik soru yer almaktadır. İkinci bölümde ise restoran seçim kararını etkileyen kriterlerden hareketle (Özdemir, 2010) katılımcıların hizmet kalitesi algısını ölçmek üzere 43 ifade yer almaktadır (Elder ve ark. 1999; Hsu, Byun \& Yang, 2008; Albayrak, 2014a; Albayrak, 2014b; Cathy-Kwok, Huang \& Hu, 2016; Akşit Aşık, 2019; Ertürk, 2019a). Bu ifadeler; yemek/menü, restoran atmosferi, hizmet sunumu (çalışanlar), fiyat ve çocuk dostu hizmet olmak üzere beş boyutu temsil etmektedir ve bu ifadeler Parasuraman ve ark.'larının (1988) hizmetin beş alt boyutunu temsil eden ifadelerdir. Katılımcıların yanıtları önem algısı için $1=$ çok önemsiz $-5=$ çok önemli, performans algısı için ise $1=$ çok düşük $-5=$ çok yüksek olacak şekilde 5'li Likert-tipi dereceleme ile derlenmiştir.

Veri toplama sürecinde temas tekniği olarak SARS-CoV-2 virüs (Covid-19) salgını nedeniyle çevrimiçi anket uygulama tekniği seçilmiştir. Birçok restoran salgın nedeniyle, restoranlardaki müşterilerle yüz yüze anket uygulamasına olumlu yaklaşmamıştır. Bu nedenle restoran yetkilileri ile görüşerek araştırmaya katkı sunmaya gönüllü olan müşterilerin e-posta adreslerinin toplanması noktasında anlaşma sağlanmıştır. Restoranlarda yemek yiyen müşterilere sosyal mesafe kuralları çerçevesinde yaklaşarak öncelikle araştırma hakkında kısa bilgi verilmiştir, ardından gönüllü olan ebeveynlerin e-posta adresleri öğrenilerek kayıt altına alınmıştır. Toplanan anketler ilgili e-posta adreslerine yollanmıştır.

Hazırlanan anket formu Mersin'deki iki farkl1 alakart restoranda, 02-09 Mart 2020 tarihleri arasında ön teste tabi tutulmuştur. 41 müşteriden bırak topla yöntemiyle toplanan veriler yüzey geçerliği ve içerik geçerliği açısından incelenmiştir. Buna göre bir ifadenin (alkollü içeceklerin bulunması) katılımcılar tarafından anlaşılmadığı ve güvenilirlik istatistiklerinden Cronbach's Alpha istatistiğini önemli ölçüde düşürdüğü anlaş1lmıştır. Sonuç olarak ilgili madde anketten çıkarılmıştır. Güncellenen anketler toplam 1652 e-posta adresine yollanmıştır. 3 kez gerçekleştirilen hatırlatma e-postaları neticesinde 10 Mart - 10 Ekim 2020 tarihleri aralığında toplam 407 katılımcıdan geri dönüş sağlanmıştır. Toplanan 407 ankete gerçekleştirilen sapan testi ve çoklu normal dağılım testi sonucunda 48 anketin veri setinden çıkartılmasına karar verilmiştir. Sonuç olarak 359 anketten oluşan veri seti bir istatistik paket programıyla çözümlenmiştir. Verilere çıkarsamalı analizler öncesinde güvenilirlik analizi yapılmıştır. Önem değişkeninin Cronbach’s Alpha istatistiği ,961, performans değişkenin ise ,972 bulunmuştur. Buradan hareketle ölçeğin iç tutarlılığının yüksek derecede güvenilir olduğu söylenebilir (Şencan, 2005: 168-170). Güvenilirlik analizlerinin ardından veri analiz 
tekniği olarak betimleyici analizlere ek olarak eşleştirilmiş t-testi ve önem-performans analizi gerçekleştirilmiştir.

\section{Bulgular}

Analize dahil edilen 359 anketten hareketle katılımcıların çoğunluğunu babaların oluşturduğu görülmüştür $(\% 67,4)$. Katılımcıların \%83,8'i 26-45 yaş aralığında, \%56'sı kamu kurum ve kuruluşlarında memur, eğitim olarak \%27,9'u lise mezunu ve \%38,4'ü lisans mezunu, \%58,2'si 3341-5442 TL arasında gelir sahibi ve \%79,7'si en fazla iki çocuk sahibidir. Katılımcılara demografik sorular dışında restoran deneyimlerine yönelik kategorik sorular da yöneltilmiştir (Tablo 1.). Buna göre katılımcıların \%72,7'si ayda en az 2-4 kez dışarıda yemek için alakart restoranları tercih ettiğini belirtmiştir. Çocuk sahibi olduktan restorana gitme sıklığı sorulan katılımcılardan, azaldı ve arttı diyenlerin oranı birbirine çok yakın iken büyük çoğunluk $(\% 43,5)$ aynı sıklıkta kaldı cevabını vermiştir.

Tablo 1. Katılımcıların Restoran Deneyimlerine Yönelik Betimleyici Bulgular ( $\mathrm{n}=359)$

\begin{tabular}{|c|c|c|c|c|c|}
\hline $\begin{array}{l}\text { Dişarıda yemek yeme } \\
\text { sıklığı }\end{array}$ & $\begin{array}{c}\text { Frekans } \\
\text { (n) }\end{array}$ & $\begin{array}{c}\text { Yüzde } \\
(\%)\end{array}$ & $\begin{array}{l}\text { Hizmet gecikme } \\
\text { süresi toleransı }\end{array}$ & $\begin{array}{c}\text { Frekans } \\
\text { (n) }\end{array}$ & Yüzde (\%) \\
\hline Ayda en fazla 1 kere & 82 & 22,8 & $1-5 \mathrm{dk}$ & 63 & 17,5 \\
\hline Ayda 2-3 kez & 153 & 42,6 & $6-10 \mathrm{dk}$ & 103 & 28,7 \\
\hline Ayda 4 kez & 108 & 30,1 & $11-15 \mathrm{dk}$ & 133 & 37,0 \\
\hline Ayda 5 ve üzerinde & 16 & 4,5 & $16-20 \mathrm{dk}$ & 50 & 13,9 \\
\hline Toplam & 359 & 100,0 & $21-25 \mathrm{dk}$ & 5 & 1,4 \\
\hline \multirow{2}{*}{$\begin{array}{l}\text { Çocuktan sonra } \\
\text { dışarıda yemek yeme } \\
\text { sıklığı }\end{array}$} & \multirow{2}{*}{$\begin{array}{l}\text { Frekans } \\
\text { (n) }\end{array}$} & \multirow{2}{*}{$\begin{array}{c}\text { Yüzde } \\
(\%)\end{array}$} & $31-35 \mathrm{dk}$ ve üzeri & 5 & 1,4 \\
\hline & & & Toplam & 359 & 100,0 \\
\hline Azald1 & 101 & 28,1 & $\begin{array}{l}\text { Daha fazla yol } \\
\text { gitmeye razi olma }\end{array}$ & $\begin{array}{l}\text { Frekans } \\
\text { (n) }\end{array}$ & Yüzde (\%) \\
\hline Değişmedi & 156 & 43,5 & $1-5 \mathrm{~km}$ & 51 & 14,2 \\
\hline Arttı & 102 & 28,4 & $6-10 \mathrm{~km}$ & 116 & 32,3 \\
\hline Toplam & 359 & 100,0 & $11-15 \mathrm{~km}$ & 136 & 37,9 \\
\hline $\begin{array}{l}\text { Daha fazla ücret } \\
\text { ödemeye razı olma }\end{array}$ & $\begin{array}{c}\text { Frekans } \\
\text { (n) }\end{array}$ & $\begin{array}{c}\text { Yüzde } \\
(\%)\end{array}$ & $16-20 \mathrm{~km}$ & 36 & 10,0 \\
\hline$\% 1-5$ & 78 & 21,8 & $21-25 \mathrm{~km}$ & 4 & 1,1 \\
\hline$\% 6-10$ & 111 & 30,9 & $26-30 \mathrm{~km}$ & 4 & 1,1 \\
\hline$\% 11-15$ & 122 & 34,0 & $31-35 \mathrm{~km}$ & 1 & 0,3 \\
\hline$\% 16-20$ & 17 & 4,7 & $36-40 \mathrm{~km}$ & 4 & 1,1 \\
\hline$\% 21-25$ & 21 & 5,8 & 41 ve daha fazla & 7 & 1,9 \\
\hline$\% 31-35$ ve üzeri & 10 & 2,8 & \multirow[t]{2}{*}{ Toplam } & \multirow[t]{2}{*}{359} & \multirow[t]{2}{*}{100,0} \\
\hline Toplam & 359 & 100,0 & & & \\
\hline
\end{tabular}

Katılımcılara yöneltilen bir başka soru grubunda çocuklarına yönelik hizmet beklentileri karşılanması durumunda katlanabilecekleri toleranslar öğrenilmiştir. Buna göre ebeveynlerin \% 64,9'u, \% 6-15 arasında daha fazla ödeme yapma, \%65,7'si 6-15 dk daha fazla servisin 
gecikmesine katlanma ve \%70,2'si 6-15 km arasında daha fazla yol gidebileceklerini ifade etmişlerdir.

\subsection{Hizmet Kalitesine Ölçeğine İlişkin Betimleyici İstatistikler ve Fark Testleri}

Katılımcıların alakart restoranlarda algıladıkları hizmet kalitesi değerlendirmeleri öncelikle ortalama ve standart sapma puanları bağlamında incelenmiş, akabinde önce bağımsız çift örneklem t-testi ile genel önem ve performans ortalamaları arasındaki fark, ardından da her bir maddenin önem ve performans durumuna göre farklılığ eşleştirilmiş t-testi ile analiz edilmiştir. Buna göre ebeveynlerin restoranlarda hizmet kalitesi beklentisi noktasında önem verdiği unsurların ortalaması 4,58 iken, bu beklentilerin karşılanmasına ait ortalama 3,74'tür. İki ortalama arasındaki fark istatistiksel olarak da anlamlıdır $(\mathrm{t}=21,062 ; \mathrm{p}<0,05)$. Benzer şekilde ölçekte yer alan 42 ifadenin eşleştirilmiş t-testi bulgularına göre tüm ifadelerin önem ve performans ortalama puanları arasındaki farklar istatistiksel olarak anlamlıdır $(\mathrm{p}<0,05)$.

Boyutlar halinde bakıldığında katılımcıların restoran tercihinde en önemli bulduğu boyut personelin davranışları $(\bar{x}=4,72)$ iken en az önemli bulduğu unsur çocuk dostu hizmetler olmuştur $(\bar{x}=4,53)$. Tekil ifadelerden hareketle ise "çalışanların kıyafetlerinin temiz olması" $(\bar{x}=4,79)$, "restoranın temiz ve hijyenik olması" ( $\bar{x}=4,78)$, "çalışanların kişisel temizlikleri" $(\bar{x}=4,77)$, "sigara içilen ve içilmeyen alanların ayrı olması" $(\bar{x}=4,75)$ ve "yemeklerde kullanılan malzemelerin taze olması" ( $\bar{x}=4,75)$ beklentilerinin en fazla önem verilenler olduğu görülmektedir. Buradan hareketle özellikle personel ve restorandan temizlik ve sağlık beklentisinin yüksek olduğu anlaşılmaktadır. Ölçek ifadelerine algılanan performans boyutları açısından bakıldığında personel, restoran ve menü/yemek boyutlarının birbirine çok yakın yükseklikte algılandığı buna karşın çocuk dostu hizmetlerin en düşük algılanan boyut olduğu görülmektedir $(\bar{x}=3,49)$. Tekil ifadelerden hareketle ise "alkollü içkilerin bulunmaması" $(\bar{x}=4,25)$, “yöresel/geleneksel yemeklerin olması" ( $\bar{x}=3,99)$, “tanınmış (marka) olması" $(\bar{x}=3,94)$ ve "personelin kişisel temizlikleri”" $(\bar{x}=3,91)$ konularının en yüksek performans algısı ortaya koyan unsurlar olduğu görülmektedir.

Ölçekteki ifadelere verilen ortalama puanlar "çocuk dostu hizmetler" açısından ayrıca incelenecek olursa en önem verilen konuların "emzirme ve alt değiştirme odası olması" $(\bar{x}=4,61)$, "mama sandalyesi/çocuk masası olması" $(\bar{x}=4,58)$ ve "oyun odasındaki oyuncakların temizliği”" $(\bar{x}=4,58)$ olduğu görülmektedir. Buna karşın “çocuk tuvaletlerinin ayrı olması" ( $\bar{x}=3,37)$, “çocuk menüsünün olması" ( $\bar{x}=3,44)$, “oyun alanından sorumlu birisinin olması" $(\bar{x}=3,45)$ ve "oyun odasının geniş olması” $(\bar{x}=3,46)$ hizmetlerinin en düşük 
performansa yol açan unsurlar olduğu anlaşılmaktadır. Detaylı betimleyici istatistikler Tablo 2.'de yer almaktadir.

Tablo 2. Önem-Performans Ortalamaları ve Fark Testi Bulguları $(n=359)$

\begin{tabular}{|c|c|c|c|c|c|c|c|}
\hline \multirow{2}{*}{$\begin{array}{c}\text { Menü / Yemek } \\
\left(\bar{x}_{\text {önem }}=4,58\right) /\left(\bar{x}_{\text {perf }}=\mathbf{3 , 8 4}\right)\end{array}$} & \multicolumn{2}{|c|}{ Önem } & \multicolumn{2}{|c|}{ Performans } & \multirow{2}{*}{$\begin{array}{c}\text { Fark } \\
\text { Ö-P }\end{array}$} & \multirow[b]{2}{*}{$\mathbf{t}$} & \multirow[b]{2}{*}{$\mathbf{p}$} \\
\hline & Ort & S.S & Ort & S.S. & & & \\
\hline $\begin{array}{l}\text { M1. Menünün tüm aile } \\
\text { bireylerine hitap eder } \\
\text { cesitlilikte olmas1. }\end{array}$ & 4,63 & ,631 & 3,88 & ,842 & 0,752 & 15,774 & ,000 \\
\hline $\begin{array}{l}\text { M2. Yemeklerin sağlıklı } \\
\text { olmas1 }\end{array}$ & 4,74 & ,525 & 3,89 & ,811 & 0,846 & 16,916 & ,000 \\
\hline $\begin{array}{l}\text { M3. Yemeklerde kullanilan } \\
\text { malzemelerin taze olmas }\end{array}$ & 4,75 & ,481 & 3,84 & ,844 & 0,908 & 18,942 & ,000 \\
\hline $\begin{array}{l}\text { M4. Menüdeki yemeklerin } \\
\text { meşhur/bilinir olması }\end{array}$ & 4,44 & ,862 & 3,76 & ,782 & 0,679 & 12,712 & ,000 \\
\hline $\begin{array}{l}\text { M5. Porsiyonların doyurucu } \\
\text { büyüklükte olması }\end{array}$ & 4,61 & ,566 & 3,89 & ,842 & 0,718 & 14,321 & ,000 \\
\hline $\begin{array}{l}\text { M6. Yemeklerin lezzetli } \\
\text { olmas1 }\end{array}$ & 4,72 & ,503 & 3,88 & ,830 & 0,846 & 16,791 &, 000 \\
\hline $\begin{array}{l}\text { M7.Kalorisi düşük (diyet) } \\
\text { yemeklerin olmas1 }\end{array}$ & 4,40 & ,998 & 3,71 & 1,009 & 0,690 & 11,144 & ,000 \\
\hline $\begin{array}{l}\text { M8. Özel sağlık durumlarını } \\
\text { dikkate alan menüler olması }\end{array}$ & 4,51 & ,883 & 3,71 & 1,063 & 0,799 & 12,980 & ,000 \\
\hline $\begin{array}{l}\text { M9. Yöresel/geleneksel } \\
\text { yemeklerin olması }\end{array}$ & 4,37 & 1,033 & 3,99 & ,873 & 0,378 & 5,698 & ,000 \\
\hline \multirow{2}{*}{$\begin{array}{c}\text { Restoran } \\
\left(\bar{x}_{\text {önem }}=\mathbf{4 , 5 7}\right) /\left(\bar{x}_{\text {perf }}=\mathbf{3 , 8 5}\right)\end{array}$} & \multicolumn{2}{|c|}{ Önem } & \multicolumn{2}{|c|}{ Performans } & Fark & \multirow[b]{2}{*}{$\mathbf{t}$} & \multirow[b]{2}{*}{$\mathbf{p}$} \\
\hline & Ort & S.s. & Ort & S.S.. & Ö-P & & \\
\hline $\begin{array}{l}\text { R1. Alkollü içkilerin } \\
\text { bulunmamas1 }\end{array}$ & 4,42 & 1,132 & 4,25 & ,917 & 0,169 & 2,764 & ,000 \\
\hline R2. Tanınmış (marka) olmas1 & 4,42 & ,968 & 3,94 & ,933 & 0,487 & 7,768 &, 000 \\
\hline $\begin{array}{l}\text { R3. Sessiz bir yemek } \\
\text { salonunun olmas1 }\end{array}$ & 4,56 & 681 & 3,88 & ,930 & 0,688 & 12,945 & ,000 \\
\hline R4. Dekorasyon kalitesi & 4,53 & ,719 & 3,84 & ,878 & 0,690 & 12,453 &, 000 \\
\hline R5. Temiz ve hijyenik olması & 4,78 & ,481 & 3,76 & ,857 & 1,022 & 20,232 &, 000 \\
\hline R6. Servisin hızlı olması & 4,64 &, 573 & 3,81 & ,900 & 0,835 & 16,476 &, 000 \\
\hline R7. Profesyonel hizmet & 4,71 & ,567 & 3,79 & ,876 & 0,922 & 18,528 &, 000 \\
\hline R8. Eve yakın olmas1 & 4,34 & 1,087 & 3,69 & ,871 & 0,651 & 10,495 &, 000 \\
\hline R9. Ulaşımın kolay olması & 4,55 &, 820 & 3,78 & 876 & 0,768 & 13,799 &, 000 \\
\hline R10. Otopark olmas1 & 4,62 & ,693 & 3,82 & ,847 & 0,796 & 15,308 &, 000 \\
\hline $\begin{array}{l}\text { R11. Oturma gruplarının rahat } \\
\text { olmas1 }\end{array}$ & 4,55 &, 752 & 3,78 & ,816 & 0,771 & 14,745 &, 000 \\
\hline $\begin{array}{l}\text { R12. Oturma gruplarının geniş } \\
\text { olmas1 }\end{array}$ & 4,55 & ,722 & 3,83 & ,866 & 0,721 & 13,947 & ,000 \\
\hline $\begin{array}{l}\text { R13. Sigara içilen ve } \\
\text { içilmeyen alanların ayrı olması }\end{array}$ & 4,75 &, 550 & 3,82 & ,838 & 0,930 & 18,451 &, 000 \\
\hline \multirow{2}{*}{$\begin{array}{c}\text { Personel } \\
\left(\bar{x}_{\text {önem }}=\mathbf{4 , 7 2}\right) /\left(\bar{x}_{\text {perf }}=\mathbf{3 , 8 6}\right)\end{array}$} & \multicolumn{2}{|c|}{ Önem } & \multicolumn{2}{|c|}{ Performans } & Fark & \multirow[b]{2}{*}{$\mathbf{t}$} & \multirow[b]{2}{*}{$\mathbf{p}$} \\
\hline & Ort & S.S. & Ort & S.S. & Ö-P & & \\
\hline $\begin{array}{l}\text { P1. Çalışanların kıyafetlerinin } \\
\text { iyi görünümlü olması }\end{array}$ & 4,66 & ,603 & 3,88 & ,858 & 0,782 & 14,896 & ,000 \\
\hline $\begin{array}{l}\text { P2. Çalışanların kıyafetlerinin } \\
\text { temiz olması }\end{array}$ & 4,79 & ,464 & 3,89 & ,870 & 0,894 & 18,213 & ,000 \\
\hline
\end{tabular}




\begin{tabular}{|c|c|c|c|c|c|c|c|}
\hline $\begin{array}{l}\text { P3. Çalışanların kişisel } \\
\text { temizlikleri }\end{array}$ & 4,77 & ,496 & 3,91 & ,819 & 0,858 & 18,295 &, 000 \\
\hline P4. Çalışanların servis bilgisi & 4,69 &, 556 & 3,85 & ,895 & 0,838 & 17,062 & ,000 \\
\hline $\begin{array}{l}\text { P5. Çalışanların nezaketi, } \\
\text { arkadaşça servis yaklaşımı }\end{array}$ & 4,69 &, 523 & 3,82 & ,852 & 0,869 & 17,906 &, 000 \\
\hline $\begin{array}{l}\text { P6. Çalışanların genel iletişim } \\
\text { becerileri }\end{array}$ & 4,70 & ,566 & 3,78 & ,878 & 0,919 & 18,061 & ,000 \\
\hline \multirow{2}{*}{$\begin{array}{c}\text { Fiyat } \\
\left(\bar{x}_{\text {onem }}=\mathbf{4 , 5 9}\right) /\left(\bar{x}_{\text {perf }}=\mathbf{3 , 7 7}\right)\end{array}$} & \multicolumn{2}{|c|}{ Önem } & \multicolumn{2}{|c|}{ Performans } & Fark & \multirow[b]{2}{*}{$\mathbf{t}$} & \multirow[b]{2}{*}{$\mathbf{p}$} \\
\hline & Ort & S.S. & Ort & S.S. & Ö-P & & \\
\hline F1. Fiyatların makul olması & 4,62 & ,615 & 3,84 & ,801 & 0,788 & 16,145 &, 000 \\
\hline $\begin{array}{l}\text { F2. Ürün fiyat aralığının geniş } \\
\text { olmas1 }\end{array}$ & 4,51 & ,700 & 3,78 & 857 & 0,735 & 14,537 &, 000 \\
\hline F3. Ödenen paraya değmesi & 4,63 &, 585 & 3,69 & ,899 & 0,938 & 19,647 &, 000 \\
\hline \multirow{2}{*}{$\begin{array}{l}\text { Cocuk Dostu Hizmetler } \\
\left(\bar{x}_{\text {onem }}=\mathbf{4 , 5 3}\right) /\left(\bar{x}_{\text {perf }}=\mathbf{3 , 4 9}\right)\end{array}$} & \multicolumn{2}{|c|}{ Önem } & \multicolumn{2}{|c|}{ Performans } & Fark & \multirow[b]{2}{*}{$\mathbf{t}$} & \multirow[b]{2}{*}{$\mathbf{p}$} \\
\hline & Ort & S.s. & Ort & S.S. & Ö-P & & \\
\hline $\begin{array}{l}\text { Ç1. Emzirme ve alt değiştirme } \\
\text { odası olması }\end{array}$ & 4,61 & ,658 & 3,60 & 877 & 1,002 & 20,053 &, 000 \\
\hline $\begin{array}{l}\text { Ç2. Mama Sandalyesi /Çocuk } \\
\text { masas1 vb. olmas1 }\end{array}$ & 4,58 & ,649 & 3,59 & ,881 & 0,991 & 19,532 & ,000 \\
\hline $\begin{array}{l}\text { Ç3. Çocuklar için oyun } \\
\text { odas1/alanının olması }\end{array}$ & 4,55 & ,635 & 3,50 & ,915 & 1,050 & 19,706 &, 000 \\
\hline $\begin{array}{l}\text { Ç4. Oyun odasının geniş } \\
\text { olması }\end{array}$ & 4,53 & ,699 & 3,46 & ,938 & 1,069 & 19,544 &, 000 \\
\hline $\begin{array}{l}\text { Ç5. Oyun odasındaki } \\
\text { oyuncakların temizliği }\end{array}$ & 4,58 & ,667 & 3,60 & 1,002 & 0,975 & 17,780 & ,000 \\
\hline $\begin{array}{l}\text { Ç6. Oyun alanından sorumlu } \\
\text { birisinin olması }\end{array}$ & 4,55 & ,698 & 3,45 & 1,015 & 1,100 & 19,119 & ,000 \\
\hline $\begin{array}{l}\text { Ç7. Çocukların için yeşil } \\
\text { alan/bahçe bulunması }\end{array}$ & 4,49 & ,712 & 3,47 & 1,072 & 1,019 & 16,324 & ,000 \\
\hline $\begin{array}{l}\text { Ç8. Çocuk tuvaletlerinin ayrı } \\
\text { olması }\end{array}$ & 4,45 & 722 & 3,37 & 1,070 & 1,083 & 18,590 & ,000 \\
\hline Ç9. Çocuk menüsünün olması & 4,54 & ,653 & 3,44 & 1,089 & 1,105 & 18,877 &, 000 \\
\hline $\begin{array}{l}\text { Ç10. Çocuklara özel yemek } \\
\text { takımlarının olması }\end{array}$ & 4,48 & ,746 & 3,36 & 1,094 & 1,119 & 18,350 &, 000 \\
\hline $\begin{array}{l}\text { Ç11. Çocuklara küçük } \\
\text { hediyeler verilmesi }\end{array}$ & 4,48 & ,735 & 3,47 & 1,079 & 1,008 & 18,108 &, 000 \\
\hline
\end{tabular}

\section{2. ÖPA Bulgulart}

Şekil 2.'de çocuklu ailelerin alakart restoranlara yönelik hizmet kalitesi algısının önem ve performans boyutunu oluşturan 42 maddeye ilişkin ÖPA matrisi bulguları yer almaktadır. Ortalama puanlara göre matrise yerleşen 42 madde, medyan puanlarından hareketle çizilen dikey $(\mathrm{y}=\ddot{\mathrm{önem}})$ ve yatay ( $\mathrm{x}=$ performans) çizgiler neticesinde dört ayrı kümeye yerleşmiştir. Buna göre ÖPA matrisinde ortaya çıkan dört küme Martilla ve James'in (1977: 78) yaklaşımından hareketle aşağıdaki gibi değerlendirilmiştir. 


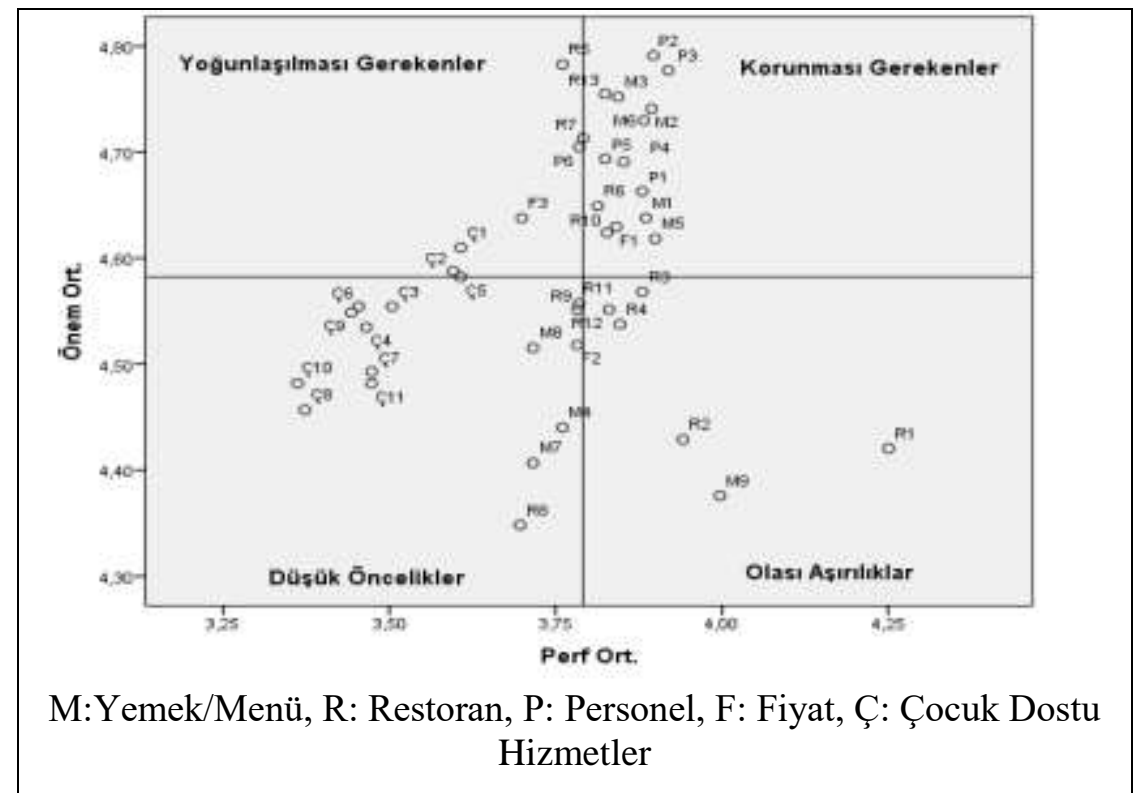

Şekil 2. ÖPA Matrisi Bulguları

Küme 1- Yoğunlaşılması Gerekenler (Yüksek Önem-Düşük Performans): Bu küme içerisindeki ifadeler müşterilerin çok önem verdiği ancak işletmelerin performansının aynı derecede karşılayıcı olmadığını gösterir. Bu noktada işletmelerin geliştirme çabaları içinde olması önerilir (Martilla ve James, 1977: 78; Albayrak, 2014b: 166; Sever, 2015: 44). Elde edilen bulgulardan hareketle çocuk dostu hizmetlerden bu kümeye giren iki ifade olduğu görülmektedir. $\mathrm{Bu}$ ifadeler emzirme ve alt değiştirme odası olması (Ç1) ve mama sandalyesi/çocuk masası olması (Ç2) ifadeleridir. Bu kategoriye giren diğer ifadeler ise alınan hizmetin ödenen paraya değmesi (F3), restoranın temiz ve hijyenik olmas1 (R5), profesyonel hizmet sunumu (R7) ve çalışanların genel iletişim becerileri (P6) şeklindedir.

Küme 2- Korunması Gerekenler (Yüksek Önem-Yüksek Performans): Bu küme içerisinde yer alan nitelikler müşterilerin çok önem verdikleri ve aynı şekilde işletmelerin bu unsurlarda iyi performans gösterdiğini ifade ederken, aynı zamanda işletmelerin güçlü yanlarını ve rekabet güçlerini de ortaya koyar (Martilla ve James, 1977: 78; Albayrak, 2014b: 166; Sever, 2015: 44). Elde edilen bulgulardan hareketle hiçbir çocuk dostu hizmetin, korunması gereken hizmetler kümesine girmediğini göstermektedir. Bu kümede yer alan 14 ifadenin dağılımına bakıldığında birçok ifade açısından restoranların menü ve personeline ait özelliklerin hem önemli hem de yüksek performansa sahip olduğu görülmektedir. Bunlara ek olarak servisin hızı (R6), otopark bulunması (R10), sigara içme alanlarının ayrı olması (R13) ve fiyatların makul olması (F1) da diğer memnuniyet sağlayıcı kritik unsurlardır.

Küme 3- Düşük Öncelikliler (Düşük Önem-Düşük Performans): Bu kümedeki ifadeler tüketicilerin hem önem hem de performans açısından düşük algıladıkları yani öncelik olmayan hizmetlerin neler olduğunu gösterir. Dolayısıyla yöneticilerin de bu hizmetlerdeki 
eksiklikler noktasında fazla endişeli olmasına gerek yoktur (Martilla ve James, 1977: 78; Albayrak, 2014b: 166; Sever, 2015: 44). Elde edilen bulgulardan hareketle 16 ifadenin bu kümeye yerleştiği görülmektedir. Bu ifadelerin dokuzu çocuk dostu hizmetlere yönelik ifadelerdir. Kümede yer alan diğer 7 ifade arasından, üç ifade restorana kolay ulaşılabilirlik ve oturma gruplarının rahatlığı (R8, R9, R11), üç ifade menülerin bilinirliği ve diyet dostu olması (M4, M7, M8) ve bir ifade de ürün fiyat aralığının geniş olmasına (F2) yöneliktir.

Küme 4- Olası Aşırılıklar (Düşük Önem-Yüksek Performans): Bu kümeye giren ifadeler müşterilerin düşük önem atfettiği ancak performansını yüksek algıladığı hizmetleri ortaya koyar. Müşterilerin seçim kararlarında önemli olmayan ancak kaliteli algılanan bu özellikler, yöneticilere eldeki kaynakları çeşitli iyileştirmeler için daha verimli kullanma noktasında rehberlik eder (Martilla ve James, 1977: 78; Albayrak, 2014b: 166; Sever, 2015: 44). Elde edilen bulgulardan hareketle, restorana yönelik atmosfer özelliklerini yansıtan bazı ifadeler (R1, R2, R3, R4, R12) ve yemeklerin yöresel/geleneksel olmas1 (M9) ifadesi bu kümede yer aldığı görülmektedir.

\section{Sonuç ve Tartışma}

\subsection{Alanyazına Yönelik Çıktılar}

Çocuklu ailelerin restoran tercihleri ve hizmet kalitesi algılarını ölçme amacıyla gerçekleştirilen bu araştırmada ortaya çıkan bulgular hem alanyazın hem de uygulamacılar için bir dizi çıktıya işaret etmektedir. Araştırma bulgularını alanyazındaki önceki araştırmalar ile iki açıdan karşılaştırmak mümkündür. Öncelikle yerli ve yabancı alanyazında sınırlı sayıda ele alınan çocuklu ailelerin restoran tercihleri açısından araştırma bulguları önceki araştırmalar ile benzer ve farklılaşan yanlara sahiptir. $\mathrm{Bu}$ araştırma neticesinde çocuklu ailelerin restoran tercihi noktasında tüm kriterleri oldukça önemli algıladığg ve 5'li Likert-tipi derecelemeye göre en düşük boyutun dahi 4,53 ortalama puana sahip olduğu anlaşılmaktadır. Boyutlar arasında bir inceleme yapıldığında en önemli unsur personelinin tutum ve davranışlarına yönelik beklentilerden oluştuğu görülmektedir. Menü içeriği, restoran atmosferi ve fiyata yönelik algılar benzer önemde yüksek puanlara sahipken, buna karşın çocuk dostu hizmetler 5 kriter arasında en az önemli olan olarak belirlenmiştir. Önceki araştırmalar ailelerin çocuk ve küçük bebekler ile gittikleri alakart restoran tercihlerinde rol oynayan başlıca unsurların; restoranın hijyeni, yemeklerin sağlıklı olması, yemeklerin fiyatı, atmosfer olarak kendilerini rahat hissetmeleri ve çocuk oyun alanlarının hijyeni olduğunu ortaya koymuştur (Elder ve ark. 1999; Pettersson \& Fjellström, 2007; Ertürk, 2009a; Ertürk, 2009b; Akşit Aşık, 2019). Dolayısıyla önceki araştırma bulguları ile bu araştırma bulguları oldukça benzemektedir. Bir diğer yandan Akşit Aşık'ın (2019) araştırmasındaki çocuk dostu 
hizmet beklentisinin aileler için tercih açısından en son sırada öneme sahip olması da araştırmamızın bulgusuyla birebir örtüşürken en önemli bulunan faktörün yemeklerin özellikleri olması araştırma bulgularımızdan farklılık göstermektedir. Bu araştırmaya katılan ebeveynler, personele yönelik hizmet kalitesi beklentisini ilk sıraya koymuştur. Benzer şekilde Elder ve ark. (1999) hızlı yemek restoranı söz konusu olduğunda çocuk menüsü beklentisinin daha ön plana çıktığı ancak alakart restoran tercihi söz konusu olduğunda salata barı ve düşük kalorili yemek beklentisinin ön plana çıktığını bulgulamıştır. Bu araştırmada yemek/menü faktörü altında en önemli görülen hizmet beklentisi; “yemeklerde kullanılan malzemelerin tazeliği” olmuştur.

Çocuk dostu hizmetler açısından restoran tercihinde rol oynayan hizmetler incelendiğinde emzirme ve alt değiştirme odası olması, mama sandalyesi/çocuk masası olması ve oyun odasındaki oyuncakların temizliği unsurları araştırmamızda ön plana çıkmıştır. Bu bulgulardan bazıları Petterson ve Fjellström (2007) ve Ertürk'ün (2019b) araştırmaları ile büyük oranda benzeşirken, Akşit Aşık’ın (2019) çalışmasındaki çocuk dostu hizmete yönelik öncelikler ile farklılaşmaktadır. Çocuklu ailelerin dışarıda yeme davranışlarını da araştıran bu çalışma neticesinde, ebeveynlerin çocuk öncesine göre dışarda yeme sıklıklarının benzer kaldığ1 ve çocukların memnun olacağı bir hizmet için fazladan ödeme yapma niyetinin \%6-15 arasında olduğu ortaya çıkmıştır. Ertürk (2019a) araştırmasında ebeveynlerin çocuk sonrası dışarda yeme sıklıklarının azaldığını ve iyi bir hizmet için \%50’ye kadar fazla ödeme yapabileceklerini bulgulamıştır. İki araştırma bulguları arasındaki farkın örneklem ve konu edilen restoran türü farklılıklarından ortaya çıkması muhtemeldir.

Araştırma bulgularının alanyazın açısından karşılaştırılabileceği bir diğer konu ise önemperformans analizi (ÖPA) açısından hizmet kalitesi algısıdır. Her ne kadar ÖPA ile hizmet kalitesi ölçümü, yiyecek içecek ve hizmet pazarlaması alanyazında sıklıkla ele alınmış olsa da çocuklu ailelerin örneklem bağlamında göz ardı edildiği ortadadır. Bu nedenle bu araştırma alanyazın için yeni bulgular ortaya koyma potansiyeline sahiptir. ÖPA neticesinde restoranların daha iyi bir hizmet adına yoğunlaşmaları gereken noktalar içerisinde çocuk dostu hizmetlere ait; "emzirme ve alt değiştirme odası olması ve mama sandalyesi/çocuk masası olması beklentileri” bulunmaktadır. Alanyazındaki ÖPA ile restoran hizmet kalitesini araştıran çalışmalarda bu iki unsur göz ardı edilmiştir. Oysa aileler restoranların en sadık müşteri gruplarının başında yer alır ve çocukları onların tüketim kararlarını etkileyen en önemli unsurlardan birisidir. Diğer araştırmalar ile benzer şekilde ise müşteriler açısından önemli olmakla beraber beklentiyi karşılamayan hizmetler; hizmetin ödenen paraya değmesi, restoranın temiz ve hijyenik olması, profesyonel hizmet sunumu ve çalışanların genel iletişim 
becerileri şeklindedir (Hsu, Byun \& Yang, 1998; Ma ve ark., 2011; Tzeng \& Chang, 2011; Obonyo ve ark., 2012; Su, 2013; Albayrak, 2014b; Liu \& Tse, 2018; Pai ve ark., 2018; Wu ve ark., 2020). Sohn \& Kim'in (2014) yemeklerin lezzeti ve servisin hızı ile Wu ve ark.'nın (2020) restoran atmosferi ve oturma takımlarının rahatlığına yönelik sorunlardan kaynaklı olarak restoranların yoğunlaşması gerektiğini ifade eden hususlar ise bu araştırma bulgularıyla farklılaşmaktadır. Aksine bu hususlar araştırmamızda restoranların koruması gereken özellikler olarak bulunmuştur. Çocuklu aileler gittikleri alakart restoranların menü çeşitliliğinden, personelin iletişim özellikleri dışındaki tüm tutum ve davranışlarından, fiyatların uygunluğundan ve servisin hızından memnun görünmektedir. Restoranların koruması gereken özelliklerin hiç birinde çocuk dostu hizmetler yer almamaktadır. Yoğunlaşılması gereken alanlarda yer alan iki çocuk dostu hizmetin dışındaki dokuz hizmet de tüketiciler için düşük öncelikli hizmetler sınıfına girmektedir. Akşit Aşık'ın (2019) çalışmasında çocuk dostu hizmetler bağlamında öne çıkan oyun odasının bulunması, yeşil alan bulunması ve çocuklara küçük hediyeler verilmesi gibi önemli beklentiler, bu araştırma neticesinde performans algıları ile kıyaslandığında düşük öncelikler sınıfına girmektedir. Diğer yandan Elder ve ark.'nın (1999) alakart restoranlar için önemli olduğunu bulguladığ1 diyet dostu ve özel sağlık durumlarını dikkate alan yemekler, bu araştırma bağlamında düşük öncelikler sınıfında kalmıştır. Ek olarak ebeveynlerin çocuklarıyla gittikleri restoranlarda yemeklerin otantikliğini öncelik olarak almadıkları da bu araştırmanın alanyazın ile benzeşen bir başka bulgusudur (Pai ve ark., 2018).

\subsection{Uygulamaya Yönelik Çıktılar}

Çalışma neticesinde elde edilen bulgular alanyazın olduğu kadar restoran işletmeleri için de katkı sağlayıcı niteliktedir. Çocuklu ailelerin restoran tercihlerinde her ne kadar çocuk dostu hizmetler yüksek öneme sahip olsa da memnuniyet sağlamada tek başına yeterli değildir. Ebeveynler için personelin hizmet sunumu ve temizliği, yemeklerde kullanılan malzemelerin taze ve sağlıklı olması ve restoranın iyi bir atmosfere sahip olması tercih açısından öncelikli unsurlardır. Bu bulgular ebeveynlerin çocuklarına rağmen, kendi rahat ve refahlarını da göz ettiklerinin bir göstergesidir. Bir restoran çocuk dostu hizmetleri ne kadar önemserse önemsesin, yemeğin ve hizmetin kendisine has özellikleri ile bütünleşmedikten sonra müşterilerin sonraki ziyaretleri için bir kriter olarak görülmeyebilir. Aileler için temel çocuk dostu hizmet kriterleri aslında bebeklere yönelik temel gereksinimlerin karşılanabileceği emzirme-alt değiştirme odası ile mama sandalyesi ve masası gibi hizmetlerdir. Ebeveynler, diğer tüm çocuk dostu hizmetleri restoranlar için düşük öncelikler arasında sınıflandırmıştır. Önem performans analizinden hareketle elde edilen bulgular bu düşünceyi desteklerken, 
işletmelerin odaklanması, koruması ve temkinli durması gereken noktaları da göstermektedir. Buna göre restoran yöneticilerinin ailelerin önemli bulup performansı düşük bulduğu emzirme ve alt değiştirme odası olması ve mama sandalyesi/çocuk masası olması hizmetlerinde iyileştirme yapması gerekmektedir. Dışarıdan bakıldığında sağlanması basit gibi görünen bu hizmetlerin karşılanmaması aileleri mutsuz edecektir. Diğer yandan aileler çalışanların ve restoranların genel fiziksel özelliklerinin çoğundan memnun olmakla beraber, restoranların temizliği, hizmet sunumundaki profesyonellik ve iletişim becerilerinin iyileştirilmesi noktasında restoranlara yol göstermektedir. En dikkat çekici hususlardan birisi de fiyatları uygun bulmakla beraber alınan hizmetin ödenen paraya değmesinde düşük performans algısıdır. Bu algının düzeltilmesi yukarıda sayılan hizmet sorunlarının bir bütün olarak aşılması ile sağlanabilecektir. Bir müşteri için restoranı terk ederken ödediği paraya değdiği düşüncesi, hem memnuniyet hem de restorana sadakat için kritik bir değerlendirmedir.

\subsection{Sinırlılıklar ve Araştırma Önerileri}

Yöntem kısmında da değinildiği üzere veriler, yaşanan SARS-CoV-2 virüs (Covid-19) pandemisi nedeniyle yalnızca araştırmacıların yaşadığı Mersin ve Adıyaman şehirlerinde ikamet eden aile bireylerinden toplanabilmiştir. SARS-CoV-2 virüs (Covid-19) pandemisi nedeniyle restoranların uzun bir süre kapalı olması ve restoranların açıldığı zaman zarfında da sosyal mesafe ve hijyen kuralları nedeniyle kontrollü bir ortamın olması, anketlerin yüz yüze toplanmasına engel olmuştur. Dolayısıyla 359 ebeveyn ile sınırlı örneklem hacmi ve veri toplamadaki temas yöntemi araştırmanın en temel sınırlılıklarıdır. İleride gerçekleştirilecek araştırmalarda bu sınırlılıkların ortadan kaldırılması, evrene daha genellenebilir bilgilerin üretilmesi açısından önemli olacaktır. Buna ek olarak, bu araştırmada ele alınmayan davranışsal eğilimler de kapsama dâhil edilerek değişkenler arası ilişkiler yapısal eşitlik modellemeleri ile test edilebilir. $\mathrm{Bu}$ araştırmada hizmet kalitesi ölçümü restoran seçim kriterleri üzerinden gerçekleştirilmiştir. Gelecekteki araştırmalarda klasik SERVQUAL ya da DINESERV kullanımı ile ÖPA tekniği ile analizler yapılabileceği gibi iki boyutlu Kano Modeli ile de (Pai ve ark., 2018) araştırmalar tasarlanabilir. Son olarak çocuklu ailelerin genel tüketiciler bağlamında ele alındığı bu araştırmanın aksine yerli ve yabancı turistler örnekleminde de araştırmalar yapılarak karşılaştırmalı bulgular sunulabilir. 


\section{KAYNAKÇA}

Aşık, Nuran Akşit. 2019. Çocuklu Ailelerin Restoran Seçimlerini Etkileyen Faktörler: İzmir'de Bir Araştırma, Güncel Turizm Araştırmaları Dergisi, 3(1): 150-168.

Albayrak, Aslı. 2014a. Müşterilerin Restoran Seçimlerini Etkileyen Faktörler: İstanbul Örneği, Anatolia: Turizm Araștırmaları Dergisi, 25(2): 190-201.

Albayrak, Aslı. 2014b. Havalimanı Restoranlarında Hizmet Kalitesinin Önem Performans Analiziyle Değerlendirilmesi, İşletme Araştırmaları Dergisi, 6(3), 157-178.

Albayrak, Tahir, and Caber, Meltem. 2011. Önem-Performans Analizi: Destinasyon Yönetimine Dair Bir Örnek/Importance-Performance Analysis: A Sample About Destination Management, Ege Akademik Bakış, 11(4): 627-638.

Arıker, Çağla. 2012. Tüketicilerin Restoran Seçiminde Kullandıkları Seçim Kriterleri ile Demografik Özellikleri Arasındaki İlişki, Öneri Dergisi, 10(38): 11-31.

Assael, Henry. 1987. Consumer Behavior and Marketing Action. Boston: PWS-Kent Publishing Company.

Auty, Susan. 1992. Consumer Choice and Segmentation in the Restaurant Industry, Service Industries' Journal, 12(3): 324-339.

Aygün, İnci, and Kazan, Halim. 2008. Aile Üyelerinin Aile Satın Alma Kararlarına Etkileri: İstanbul Uygulamas1, Sosyal Ekonomik Araştırmalar Dergisi, 8(15): 227-248.

Aymankuy, Yusuf, and Ceylan, Uğur. 2013. Ailelerin Turistik Ürün Satın Alma Karar Sürecinde Çocukların Rolü: Yerli Turistler Üzerinde Bir Araştırma, Elektronik Sosyal Bilimler Dergisi, 12(45): 105-122.

Babin, Barry. J., Lee, Yong. Ki., Kim, Eun. Ju, and Griffin, Mitch. 2005. Modeling Consumer Satisfaction and Word-Of-Mouth: Restaurant Patronage in Korea, Journal of Services Marketing, 19(3): 133-139.

Carlson, Les, and Grossbart, Sanford. 1988. Parental Style and Consumer Socialization of Children, Journal of Consumer Research, 15: 77-94.

Cathy-Kwok, Linchi., Huang, Yung. Kuei. and Hu, Lanlan. 2016. Green Attributes of Restaurants: What Really Matters to Consumers?, International Journal of Hospitality Management, 55: 107-117.

Chen, Li. Fei. 2014. A Novel Framework for Customer-Driven Service Strategies: A Case Study of a Restaurant Chain, Tourism Management, 41: 119-128.

Chen, Yang. Su., Lehto, Xinran., Behnke, Carl, and Tang, Chun. Hung. 2016. Investigating Children's Role in Family Dining-Out Choices: Evidence from a Casual Dining Restaurant, Journal of Hospitality Marketing \& Management, 25(6): 706-725.

Chiang Leong, Choon. 2008. An Importance-Performance Analysis to Evaluate Airline Service Quality:The Case Study of a Budget Airline in Asia, Journal of Quality Assurance in Hospitality \& Tourism, 8(3): 39-59.

Choi, Mi. Kyung, and Jung, Jae. Chan. 2006. The Importance-Performance Analysis of Bakery Cafe Choice Attributes Perceived by Customers in Seoul, Journal of the Korean Society of Food Science and Nutrition, 35(4): 456-463.

Chu, Raymond, and Choi, Tat. 2000. An Importance-Performance Analysis of Hotel Selection Factors in the Hong Kong Hotel Industry: A Comparison of Business and Leisure Travellers, Tourism Management, 21(4): 363-377.

Cronin Jr, J. Joseph., Brady, Michael. K, and Hult, G. Tomas M. 2000. Assessing The Effects of Quality, Value, and Customer Satisfaction on Consumer Behavioral Intentions in Service Environments, Journal of Retailing, 76(2): 193-218.

Cronin Jr, J. Joseph. and Taylor, Steven. A. 1992. Measuring Service Quality: A Reexamination and Extension, The Journal of Marketing, 56(3): 55-68.

Cunningham, Isabella. C. M, and Green, Robert. T. 1974. Purchasing Roles in The US Family, 1955 and 1973, Journal of Marketing, 38(4): 61-64.

Elder, John., Sallis, James. F., Zive, Michelle.M., Hoy, Patricia., McKenzie, Thomas. L., Nader, Philip. R, and Berry, Charles. C. 1999. Factors Affecting Selection of Restaurants by Anglo-and Mexican-American Families, Journal of the American Dietetic Association, 99(7): 856-858.

Erdoğan, Dilek. 2020. Havaalanı Hizmet Kalitesinin Önem-Performans Analiziyle Değerlendirilmesi: Gaziantep Havalimanı Örneği, Journal of Aviation Research, 2(2): 82-100.

Ertürk, Müjdat. 2019a. Çocuklu Ailelerin Dışarıda Yeme Alışkanlıkları, Gaziantep University Journal of Social Sciences, 18(4): 1592-1610.

Ertürk, Müjdat. 2019b. Çocukla Yemeğe Çıkmak: Ailelerin Bakışlarına Yönelik Nitel Bir Araştırma, Journal of Tourism and Gastronomy Studies, 7(2): 785-804.

Filiatrault, Pierre, and Ritchie, J. R. Brent. 1980. Joint Purchasing Decisions: A Comparison of Influence Structure in Family and Couple Decision Making Units, Journal of Consumer Research, 7(2): 131-140.

Flurry, Laura. A. 2007. Children's Influence in Family Decision-Making: Examining the Impact of the Changing American Family, Journal of Business Research, 60(4): 322-330. 
Gronroos, Christian. 1988. Service Quality: The Six Criteria of Good Perceived Service, Review of Business, 9(3): 10-13.

Ha, Jooyeon, and Jang, SooCheong. Shawn. 2010. Effects of Service Quality and Food Quality: The Moderating Role of Atmospherics in An Ethnic Restaurant Segment, International Journal of Hospitality Management, 29(3): 520-529.

Ha, Jooyeon, and Jang, SooCheong. Shawn. 2009. Perceived Justice in Service Recovery and Behavioral Intentions: The Role of Relationship Quality, International Journal of Hospitality Management, 28(3): 319-327.

Han, Xiaoyun., Kwortnik Jr, Robert. J, and Wang, Chunxiao. 2008. Service Loyalty: An Integrative Model and Examination Across Service Contexts, Journal of Service Research, 11(1): 22-42.

Hansen, Eric, and Bush, Robert. J. 1999. Understanding Customer Quality Requirements: Model and Application, Industrial Marketing Management, 28(2): 119-130.

Hart, Christopher. W., Heskett, James. L. and Sasser Jr, W. Earl. 1990. The Profitable Art of Service Recovery, Harvard Business Review, 68(4): 148-156.

Howard, Dennis. R. and Madrigal, Robert. 1990. Who Makes the Decision: The Parent or Child? The Perceived Influence of Parents or Children on the Purchase of Recreation Services, Journal of Leisure Research, 22(3): 244-258.

Hsu, Cathy.H.C., Byun, Sunghee, and Yang, II. Sun. 1998. Attitudes of Korean College Students Towards Quick-Service, Family-Style, and Fine Dining Restaurants, Journal of Restaurant \& Foodservice Marketing, 2(4): 65-85.

Hudson, Simon, and Shephard, Graham. W. 1998. Measuring Service Quality at Tourist Destinations: An Application of Importance-Performance Analysis to An Alpine Ski Resort, Journal of Travel \& Tourism Marketing, 7(3): 61-77.

Jeng, Chi. Ruey., Snyder, Adam. T, and Chen, Ching. Fu. 2019. Importance-Performance Analysis as A Strategic Tool for Tourism Marketers: The Case of Taiwan's Destination Image, Tourism and Hospitality Research, 19(1): 112-125.

John, Deborah. Roedder. 1999. Consumer Socialization of Children: A Retrospective Look at Twenty-Five Years of Research, Journal of Consumer Research, 26(3): 183-213.

Kara, Ali., Kaynak, Erdener, and Küçükkemiroğlu, Orsay. 1996. Positioning of Fast-Food Outlets in Two Regions of North America: A Comparative Study Using Correspondence Analysis, Journal of Professional Services Marketing, 14(2): 99-119.

Karasar, Niyazi. 2014. Bilimsel Araştırma Yöntemi. Ankara: Nobel Yayın Dağıtım.

Kaya, Ozan. 2017. Turistlerin Kruvaziyer Gemileri Yiyecek ve İçecek Hizmetlerinden Beklenti ve Performans Düzeylerine İlişkin Bir Araştırma, Journal of Tourism and Gastronomy Studies, 5: 22- 38.

Kılıç, Burhan., Esen, Turgay, and Esen, Funda. Ön. 2017. Günübirlik Kültür Turlarında Alınan Yiyecek Hizmetinin Önem-Performans Analizi İle Değerlendirilmesi. III. Uluslararası Girişimcilik, İstihdam ve Kariyer Kongresi, Muğla, 725-737.

Kılıç, Burhan., Ok, Serap, and Sop, Serhat. Adem. 2013. Otel İşletmelerinde Müşteri Şikâyetlerinin Değerlendirilmesi ve Hizmet Kalitesi Algısının Müşteri Sadakati Üzerine Etkisi, University of Gaziantep Journal of Social Sciences, 12(4): 817-836.

Koç, Erdoğan. 2008. Tüketici Davranışları ve Pazarlama Stratejileri, Global ve Yerel Yaklaşım. Ankara: Seçkin Yayıncilik.

Kotler, Philip., Bowen, John. T, and Makens, James. C. 2010. Marketing for Hospitality and Tourism. (5th Ed.). New York: Pearson Education Inc.

Labrecque, JoAnne, and Ricard, Line. 2001. Children's Influence on Family Decision-Making: A Restaurant Study, Journal of Business Research, 54: 173-176.

Lee, Yong. Ki., Park, Kyung. Hee., Park, Dae. Hwan., Lee, Kyung. Ah, and Kwon, Yong. Ju. 2005. The Relative Impact of Service Quality on Service Value, Customer Satisfaction and Customer Loyalty in Korean Family Restaurant Context, International Journal of Hospitality \& Tourism Administration, 6(1): 27-51.

Liu, Pei, and Tse, Eliza. Ching. Yick. 2018. Exploring Factors on Customers' Restaurant Choice: An Analysis of Restaurant Attributes, British Food Journal, 120(10): 2289-2303.

Ma, Emily., Qu, Hailin, and Njite, David. 2011. US Customer Perceptions Toward Chinese Restaurant Service Quality: An Importance and Performance Approach, Journal of Foodservice Business Research, 14(3): 290-308.

Mangleburg, Tamara. F., Grewal, Dhruv, and Bristol, Terry. 1999. Family Type, Family Authority Relations, and Adolescents, Advances in Consumer Research, 26: 379-384.

Martensen, Anne, and Grønholdt, Lars. 2008. Children's Influence on Family Decision Making, Innovative Marketing, 4(4): 14-22.

Martilla, John. A, and James, John. C. 1977. Importance Performance Analysis, Journal of Marketing, 41(1): $77-$ 79 . 
Miller, Kenneth. E, and Ginter, James. L. 1979. An Investigation of Situational Variation in Brand Choice Behavior and Attitude, American Marketing Association, 16(1): 111-123.

Nayak, Sudhansu. Sekhar. 2015. Eat Out: Children's Role in Family Decision Making, International Education and Research Journal, 1(5): 95-99.

Nelson, James. E. 1979. Children As Information Sources in the Family Decision to Eat Out, Advances in Consumer Research, 6: 419-423.

Norgaard, Maria. Kümpel., Bruns, Karen., Christensen, Pia. Haudrup, and Mikkelsen, Miguel. Romero. 2007. Children's Influence on and Participation in the Family Decision Process During Food Buying, Young Consumers, 8(3): 197-216.

Obonyo, George. Otieno., Ayieko, Monica. Awuor, and Kambona, Oscar. Ouma. 2012. An ImportancePerformance Analysis of Food Service Attributes in Gastro-Tourism Development in Western Tourist Circuit, Kenya, Tourism and Hospitality Research, 12(4): 188-200.

Özdemir, Bahattin. 2010. Dışarıda Yemek Yeme Olgusu: Kuramsal Bir Model Önerisi, Anatolia: Turizm Araştırmaları Dergisi, 21(2): 218-232.

Pai, Fan. Yun., Yeh, Tsu. Ming, and Tang, Cheng. Yeh. 2018. Classifying Restaurant Service Quality Attributes by Using Kano Model and IPA Approach, Total Quality Management \& Business Excellence, 29(3-4): 301-328.

Parasuraman, Anantharanthan., Zeithaml, Valarie. A, and Berry, Leonard. L. 1985. A Conceptual Model of Service Quality and Its Implications for Future Research, The Journal of Marketing, 49(4): 41-50.

Parasuraman, A., Zeithaml, Valarie. A, and Berry, Leonard. L. 1988. SERVQUAL: A MultipleItem Scale for Measuring Consumer Perceptions of Service Quality, Journal of Retailing, 64(1): 12-40

Pedraja Iglesias, Marta, and Jesus Yagüe Guillén, M. 2004. Perceived Quality and Price: Their Impact on the Satisfaction of Restaurant Customers, International Journal of Contemporary Hospitality Management, 16(6): 373-379.

Pettersson, Anette, and Fjellström, Christina. 2007. Restaurants as Friends of the Family: Functions of Restaurant Visits in Everyday Life, Journal of Foodservice, 18: 207-217.

Ryu, Kisang, and Han, Heesup. 2010. Influence of the Quality of Food, Service and Physical Environment on Customer Satisfaction and Behavioral Intention in Quick-Casual Restaurants: Moderating Role of Perceived Price, Journal of Hospitality \& Tourism Research, 34(3): 310-329.

Sever, Ivan. 2015. Importance-Performance Analysis: A Valid Management Tool?, Tourism Management, 48, 43-53.

Sohn, Jeong. Min, and Kim, Hak. Seon. 2014. A Study on the Foodservice Quality of Japanese Restaurants Using the Importance-Performance Analysis (IPA), Culinary Science and Hospitality Research, 20(2): 199-213.

Stevens, Pete., Knutson, Bonnie, and Patton, Mark. 1995. DINESERV: A Tool for Measuring Service Quality in Restaurants, The Cornell Hotel and Restaurant Administration Quarterly, 36(2): 5-60.

Su, Ching. Shu. 2013. An Importance-Performance Analysis of Dining Attributes: A Comparison of Individual and Packaged Tourists in Taiwan, Asia Pacific Journal of Tourism Research, 18(6): 573-597.

Swinyard, William. R, and Sim, Cheng. Peng. 1987. Perception of Children's Influence on Family Decision Processes, The Journal of Consumer Marketing, 4(1): 25-38.

Szybillo, George. J, and Sosanie, Arlene. 1977. Family Decision Making: Husband, Wife and Children, Advances in Consumer Research, 4, 46-49

Şencan, Hüner. 2005. Sosyal ve Davranışsal Ölçümlerde Güvenilirlik ve Geçerlilik. Ankara: Seçkin Yayıncılık.

Şen Demir, Şirvan, and Kozak, Metin. 2013. Tüketici Davranışları. Ankara: Detay Yayıncılık.

Tam, Jackie. L. 2004. Customer Satisfaction, Service Quality and Perceived Value: An Integrative Model, Journal of Marketing Management, 20(7-8): 897-917.

Tekin, Ömer. Akgün., Kalkan, Gürkan, and Duman, Hüseyin. 2014. Hizmet Kalitesinin Önem-Performans Analizi ile Ölçülmesi: Üniversite Sosyal Tesislerinin Konaklama Üniteleri Üzerinde Bir Uygulama, Journal of International Social Research, 7(31): 751-770.

Tetik, Nuray. (2012). Turist Rehberlerinin Ekoturizm Alanındaki Yeterliliklerinin Önem-Performans Analizi, Seyahat ve Otel Işletmeciliği Dergisi, 9(3): 6-24.

Tsai, Wen. Hsien., Hsu, Wei, and Chou, Wen. Chin. 2011. A Gap Analysis Model for Improving Airport Service Quality, Total Quality Management \& Business Excellence, 22(10): 1025-1040.

Tzeng, Gwo. Hshiung, and Chang, Hung. Fan. 2011. Applying Importance-Performance Analysis As A Service Quality Measure in Food Service Industry, Journal of Technology Management \& Innovation, 6(3): 106-115.

Valkenburg, Patti. M. and Cantor, Joanne. 2001. The Development of A Child Into A Consumer, Applied Developmental Psychology, 22: 61-72.

Wu, Tai. Hsi., Weng, Shao. Jen., Lin, Yi. Ta., Kim, Seung. Hwan, and Gotcher, Don. 2020. Investigating the Importance and Cognitive Satisfaction Attributes of Service Quality in Restaurant Business - a Case Study of TASTy Steakhouse in Taiwan, Journal of Foodservice Business Research, 23(4): 236-284. 
Güler, O., Yayla, F., Öztürk, M. / Journal of Yasar University, 2021, 16/61, 170-191

Yang, Wan, and Mattila, Anna. S. 2012. The Role of Tie Strength on Consumer Dissatisfaction Responses, International Journal of Hospitality Management, 31(2): 399-404.

Yüksel, Atila, and Yüksel, Fisun. 2003. Measurement of Tourist Satisfaction With Restaurant Services: A Segment-Based Approach, Journal of Vacation Marketing, 9(1): 52-68.

Yoon, Hei. Ryeo. 2008. A Study on Consumer Service Encounters at a Large Food Court Customer Using Importance-Performance Analysis, The Korean Journal of Food and Nutrition, 21(1): 97-105.

Zhang, Hanqin. Q, and Chow, Ivy. 2004. Application of Importance-Performance Model in Tour Guides' Performance: Evidence From Mainland Chinese Outbound Visitors in Hong Kong, Tourism Management, 25: 81-91. 